sciences underpinning psychiatry and act as a hurdle to weed out those who weren't up to further training. The result of failing so many people is that trainees spend more and more time during their clinical training in studying and revising material for the Preliminary Test. This inevitably prevents them from committing themselves fully to clinical studies and their training suffers in consequence.

So can anything be done? I would like to suggest two possibilities. Ideally the Preliminary Test should be abolished altogether. Far from being a small hurdle it has taken on the proportions of Bechers Brook. Why not have one exam in which basic sciences, psychopathology and clinical matters are all integrated together? But perhaps this is too radical a step to consider, so as a second alternative why not establish a pass mark so that however many people reach that mark will be deemed to have passed the exam. If everyone passes, Hurrah, it means that training courses and standards generally have improved.

I am deeply concerned that the examiners may be out of touch with what is going on at the grass roots and I would be very interested to hear the views of other readers.

M. A. Sevitt

Long Grove Hospital

Epsom, Surrey

\section{Psychiatry and its stigma}

\section{Dear Sirs}

I was recently in Washington DC where I attended the 139th Annual Meeting of the American Psychiatric Association (APA). I was greatly influenced by the amount of effort being invested by the APA into a campaign to reduce the stigma associated with mental illness and the prejudice shown by society in general and the rest of the medical profession in particular toward psychiatrists. The incoming president, Dr Robert O. Pasnau MD, stressed that, aside from the problems of medical liability, the new DSM IIIR, and the allocation of a reasonable Federal budget toward mental illness, he regarded the question of the stigma of psychiatry as a priority issue. The allocation of two full symposia on this topic together with a major lecture by Jack Hinckley (founder of the American Mental Health Fund following the shooting of President Reagan by his son) reflected this concern. An impressive array of weaponry has been assembled in the APA's armamentarium to combat this problem. A major publicity campaign will soon be mounted on radio and national network TV, aiming to de-mystify mental illness. The securing of a $9 \frac{1}{2}$ million dollar aid package from the US Advertising Council adds considerable financial weight to this programme, which is backed up by a subsidiary campaign on 'depression and its ART-awareness, recognition and treatment'. Congressmen, media personalities, prominent public figures and professional marketeers have all been recruited to help. The National Association of the Mentally Ill and the American Medical Health Fund have promised support. The birth of the National Association for Depression and manicdepressive illness on Capitol Hill while all this was being discussed in the conference added weight to the APA's argument.

Finally, and perhaps most important of all, the APA is plannning a physician's awareness campaign to try and alter the way our colleagues in other specialities regard psychiatrists. The message is simple. The stigma attached to psychiatry has hindered effective psychiatric care and caused anguish to American psychiatrists for too long, and the APA has determined to try and rectify the situation. Whilst some of their tactics may not be applicable to the UK (although professional marketing consultants are now employed by all three major political parties), the basic need for action on this issue clearly is, and I would hope that in due course the Royal College of Psychiatrists would generate its own initiative. It is high time that the remark 'You're the only sane psychiatrist I know'1 became an echo from the past.

\section{Queen Elizabeth Military Hospital \\ Woolwich SE18}

\section{G. E. VINCENTI}

\section{REFERENCE}

${ }^{1}$ Fink, Paul J. (1984) You are the only sane psychiatrist I know. Journal of the American Medical Association, 5, 611.

\section{Psychoanalysis: natural or human science? DeAr Sirs}

I was very interested to read Carola Mathers' article in the recent Bulletin ${ }^{1}$ and agree with her that 'as psychiatrists we need to keep open minds as to what constitutes scientific activity' and also, 'that to consider levels of explanation unfamiliar to us as being nonscience. . . is to impoverish our understanding...'

The reader will be familiar with Jaspers' claim $^{2}$ that psychoanalysis is a discipline using empathetic understanding which mistakes itself to be a causal science similar to the natural sciences. I want to propose here (by-passing a more fundamental critique of Bhaskar's theory of science which would be better left to a philosopher) that Bhaskar's 'transcendental realism' ${ }^{3}$ leads to a rather similar conclusion: Bhaskar argues that causal explanations are equally applicable in the natural as in the human sciences. The fundamental difference between the two lies in the way the 'generative mechanisms' are being identified: while in the natural sciences these mechanisms can be directly observed or experienced by their effects (like in the case of a magnetic or gravitational field), in the human sciences they have to be identified by an hermeneutic analysis. Whether conscious (or unconscious) reasons are causally effective or mere rationalisations, or even pretended, can only be determined by comparing the given reason with its situational context, the history and personality of the subject, and in negotiation with him or her. In this process of empathetic understanding as described by Jaspers, ${ }^{2}$ the particular reason is illuminated by its situational and psychological context-in 
return it offers a reflection on the whole of the subject's personality (life-situation, history etc., which are assembled from a multitude of actions, motives and reasons as they are observed by us). Here we have the hermeneutic circle which is not really circular, as Will ${ }^{4}$ would have it, but leads by each revolution to a deeper, richer and more accurate, but of course never complete, understanding.

Thus, unlike Will, who rejects both a Popperian and an hermeneutic interpretation of psychoanalytic method, his philosophical mentor Bhaskar would accept the limitations of the human sciences in their dependence on understanding to define their generative mechanisms.

University of Aberdeen

K. P. Ebmeiter

Department of Mental Health

Aberdeen

References

${ }^{1}$ MAthers, C. B. B. (1986) Psychoanalysis: Science or nonscience? Bulletin of the Royal College of Psychiatrists, 10, 103-104.

${ }^{2}$ JAspens, K. (1963) General Psychopathology, Manchester University Press.

${ }^{3}$ Bhaskar, R. (1979) The Possibility of Naturalism. Brighton: The Harvester Press.

'WILL, D. (1983) Transcendental realism and the scientificity of psychoanalysis. British Journal of Medical Psychology, 56, 371-378.

\section{Dear Sirs}

Whilst sharing Dr Mathers ${ }^{1}$ concern at the uncritical use of some of Karl Popper's writings to justify a particular position with regard to psychoanalysis, I feel less hopeful that a descriptive model of science which includes psychoanalysis will provide psychiatry with sufficient justification for research into its practical applications. There is an absurdity in a description of science which leads to the conclusion that the activities of the nuclear physicist and the psychoanalyst are similar in a way which is more important than their differences and that the similarity means psychoanalysis is inescapably scientific, sensible and fit for research. The analogy, it seems, changes only the status of the analyst and not the physicist.

Indeed, it is not clear that definition is the most valuable contribution the philosophy of science makes to psychiatry or if such definition is at all possible. Some philosophers, like Laudan', feel that 'The quest for a specifically scientific form of knowledge, or for a demarcation criterion between science and nonscience has been an unqualified failure ... it is time we abandoned that lingering scientistic prejudice which holds that the 'sciences' and sound knowledge are co-extensive: they are not'.

Surely more challenging, but ultimately more rewarding than description and definition, is to attempt to apply logic, epistemology and metaphysics to our intellectual enquiry irrespective of its scientific status in order to determine 'what principles are assumed in the use of time honoured methods of acquiring knowledge' ${ }^{3}$ If psychoanalysis provides logical reasoning, a clear conceptual framework, and a coherent theory of knowledge, why should the status of nonscience in itself lead us to regard it as nonsense?

RACHEL M. A. BROWN

The Maudsley Hospital

London SES

References

'Matreres, Carola B. (1986) Psychoanalysis: science or nonscience? Bulletin of the Royal College of Psychiatrists, 10, 103-104.

2LAUDAN, L. (1981) A problem solving approach to scientific progress. In Scientific Revolutions (ed. I. Hacking). Oxford University Press.

${ }^{3}$ Harre, R. (1985) The Philosophies of Science-An Introductory Survey. Oxford University Press.

\section{The Yorkshire Regional Psychiatric Association-an appeal for memories}

DeAr SirS

The Leeds Regional Psychiatric Association was founded on 24 January 1949. Open to psychiatrists, psychologists, social workers, chaplains, nurses and others working in the field of mental health, it claims the distinction of being the first inter-disciplinary society of professional workers in mental health to be established in the United Kingdom.

In May 1982, to maintain consistency with NHS administrative reorganisation, the Association changed its title to the Yorkshire Regional Psychiatric Association.

The 40th Anniversary of the Association will fall in 1989 and its Executive Committee has discussed marking this achievement with a publication. The Association is therefore seeking to complete its records as far as possible.

If any psychiatrists who have had past membership of the Association can supply information and memories from old programmes, diaries and recollections, their help will be gratefully appreciated by the Association.

Meanwood Park Hospital Honorary Secretary

\section{Is psychiatry stigmatising?}

\section{DeAr Sirs}

Turner has recently reviewed some of the attempts to reduce the stigma attached to the receipt of psychiatric services, and concludes that in order to reduce stigma it is necessary to improve the status of psychiatry. ${ }^{2}$ I can understand that this conclusion might appeal to psychiatrists, if only on the basis of self interest, but there are grounds for scepticism. There has been extensive research in the US into the grounds for the rejection of mentally ill people. It is never possible to generalise with confidence between different countries, but the evidence that there is suggests that the problem of stigma, and the rejection of people who are mentally ill, is more complex than Turner's analysis suggests.

Turner asks why mental illness should be rejected more than other complaints, like multiple sclerosis or diabetes. It 